\title{
Letters from the Front and Memoires in a Museum Exhibition as the Means of Commemoration and Formation of Historical Memory
}

\section{Cartas de portada y memorias en una exposición de museo como medio de conmemoración y formación de la memoria histórica}

\author{
Bella A. Nochvina \\ Linguistics University of Nizhny Novgorod, Nizhny Novgorod, Russia \\ ORCID: 0000-0003-0772-9817 \\ Nina V. Starikova \\ Minin Nizhny Novgorod State Pedagogical University, Nizhny Novgorod, Russia
} ORCID: 0000-0001-6631-0296

Anna V. Shurshikova

Minin Nizhny Novgorod State Pedagogical University, Nizhny Novgorod, Russia ORCID: 0000-0002-8012-4630

Leonid N. Akimov

Linguistics University of Nizhny Novgorod, Nizhny Novgorod, Russia ORCID: 0000-0002-6246-6282

\section{Ekaterina A. Akimova}

Nizhny Novgorod Institute of Management - branch of the Russian Presidential Academy of National Economy and Public Administration (RANEPA), Nizhny Novgorod, Russia ORCID: 0000-0002-3645-7294 


\section{Summary}

The article researches the process of historical memory formation and the role of museum spaces in it. The authors consider the use of letters from the front as the means of commemoration. The issues of commemoration and re-commemoration, museum reflection and its influence on historical memory are studied. Special attention is paid to museumification of front letters and memoires of war workers. The authors consider the new possibilities of using them in museum displays using multimedia technologies, emphasizing the higher accessibility of the letters' content in multimedia. The research novelty consists in the cross-disciplinary view of a historical source through the prism of museum space. The authors show the properties and possibilities of narrative sources which are now available due to modern technologies. The unpublished ego-documents (private letters and memoires) from museum funds were studied and described. The research topicality is due to identification of the influence of written museum exhibits on the formation and socialization of historical memory. It is proved that the personal materials in a museum display using modern technical opportunities enhance the informative effect, stimulating commemoration and facilitating the formation of historical memory. The article employs the experience of fund, exhibition and excursion work of the Museum of the history of Gorky railroad development.

Keywords: Memorial places, Museum-related reflection, Socialization of historical memory, Public conscience, Reconstructing the past, Museumification.I

\section{Resumen}

El artículo investiga el proceso de formación de la memoria histórica y el papel de los espacios museísticos en él. Los autores consideran el uso de letras del frente como medio de conmemoración. Se estudian los temas de la conmemoración y re-conmemoración, la reflexión museística y su influencia en la memoria histórica. Se presta especial atención a la museificación de las portadas y memorias de los trabajadores de guerra. Los autores consideran las nuevas posibilidades de utilizarlas en exposiciones de museos utilizando tecnologías multimedia, haciendo hincapié en la mayor accesibilidad del contenido de las cartas en multimedia. La novedad de la investigación consiste en la mirada transversal de una fuente histórica a través del prisma del espacio museístico. Los autores muestran las propiedades y posibilidades de las fuentes narrativas que ahora están disponibles gracias a las tecnologías modernas. Se estudiaron y describieron los documentos ego inéditos (cartas privadas y memorias) de los fondos del museo. La actualidad de la investigación se debe a la identificación de la influencia de las exhibiciones escritas en los museos en la formación y socialización de la memoria histórica. Está comprobado que los materiales personales en una exhibición de museo que utilizan las oportunidades técnicas modernas mejoran el efecto informativo, estimulan la conmemoración y facilitan la formación de la memoria histórica. El artículo emplea la experiencia del trabajo de fondos, exposiciones y excursiones del Museo de la historia del desarrollo del ferrocarril de Gorky.

Palabras clave: Lugares conmemorativos, Reflexión museística, Socialización de la memoria histórica, Conciencia pública, Reconstrucción del pasado, Museumificación.

\section{Introduction}

Museum exhibitions, as the material expression of the gone and irrevocable past, continue playing the leading role in commemoration, i.e. in the process of preserving in the public conscience the events which are most important for national self-identification. Undoubtedly, commemoration is actualized as the means to fix historical memory in the modern world. The modern post-industrial society is characterized not only by the socio-cultural mosaicism, mutual 
influence of deideologization and search for a new super-ideology, but also by the striving of states to preserve their national identity as the basis of independence of foreign policy development vector under the growing globalization. For a modern state, protecting the historical memory is the objective of supporting one's inner political integrity, its protection against the foreign-policy challenges of the informational society. Unfortunately, today's destabilization of many social structures, such as national parties, the national state, traditionalist public organizations, turns the notion of "historical memory" into a means of political struggle, conscious manipulation of the public opinion. In this regard, studying the possibilities of a museum exhibition as an effective means of commemoration becomes especially topical. In this context, the exhibition space serves as the memorial place, the main function of which is to fix the events, significant for the society's self-identification, in its historical conscience (Repina, 2010). The research object is the mechanisms of the exhibition items' influence on commemoration, as well as the influence of modern multimedia technologies on this process. The research is based on the materials of the section, devoted to the Great Patriotic War, in the corporate museum of the history of Gorky railroad development (PZhD Public Corporation). The research objective is to study the changes in attractive features of war letters and memoires which occurred due o the use of modern museum technologies, and their influence on commemoration of formation of the historical memory about the war. To achieve the set objective, we solved the following tasks: analyzed the historiography tradition related to the issues of public and historical conscience, collective and historical memory, their correlation, structure and properties; studied the issue of the position and role of historical memory in the process of commemoration; researched the ego-documents of the museum exhibition and their influence on fixing the specific event - the Great Patriotic War - in the historical conscience of the society; considered the new possibilities for translating the inner, emotional content of the personal sources through using the multimedia technologies in a museum, as well as the growth of their attractive impact on the exhibition visitors.

\section{Literature review}

Analyzing the polemical discourse in order to estimate the equality of the historical and collective memory (Leontyeva, 2015) and the combination of historical memory and historical conscience in the Russian and foreign historiography, we should note that, in our opinion, it is necessary to overcome the antagonism of historical science and collective memory; maintenance of this antagonism has a destructive impact on the functioning of all forms of historical memory and reinforces the process of oblivion.

Museums as a form of memorial places may become an important means of overcoming the contradictions between scientific knowledge and collective memory. By the definition of Pierre Nora, a museum space is a "memorial place", uniting the material remains of event gone to the past and its spiritual constituent (Nora, 1999). A museum grants the best opportunity for uniting the material and the spiritual components in a single image and for inculcating it in the conscience of a lot of people of various genders, ages, and social statuses (Smirnov, 2016). Through creating and establishing such images in the public conscience, the continuous communication between times and generations takes place.

A museum as an expression of commemoration serves as not only a historical reconstruction but also an embodiment of a varied notion of "a memorial place" with its rich functional potential, including through representation of the narratives, exhibited in a museum, and the visualization of the past, recreated in them (Ovchinnikova, 2017). Given the modern multimedia technologies, museums may compete with cinema works in reconstructing the past, with the reconstructions based on reliable facts and sources and, at the same time, having a high degree of demonstrativeness and emotional expressivity. 


\section{Materials and methods}

Exhibition of a museum of any type includes three main components, without which it is impossible to create an adequate image of an epoch, an event, or a fact. First, it is authentic objects - the remains of a certain historical epoch, having a handmade or a natural origin. On these exhibits the museum display is built, they form the center of the exhibition space, and a visitor's attention is focused on them with the help of various techniques. However, not all authentic objects possess the necessary degree of attraction and ability to make the relevant impression. Often they are "enhanced" with models or accompanying information. Models form the second component of the exhibition space. They enable to reconstruct a long lost process, visualize an event or phenomenon of the past. Supplemented with the necessary information, which is the third component of the exhibition, they form a complete image, possessing the necessary degree of reliability and informative value and able to produce the sufficient emotional impression ${ }^{1}$.

The research was mainly based on the narrative inheritance of museum funds, which is still the cornerstone of scientific concept of exhibitions. As technical equipment of museums develops and they move towards interactivity and multimedia implementation, it acquired new life in a museum space. While traditionally the sets of written sources were accessible for a visitor as an external illustration and confirmation of an accomplished fact only, and the content and emotional components were left "off-screen" and were accessible by the scientific community only, now the situation is entirely different. The modern technologies allow using written evidences not only in visual, but also content aspect, creating maximally "powerful" and emotionally charged images in a museum space (Navarro, 2010). Of the most expressed inner character are personal documents - letters and memoires of the participants of the events, thus, they should be used to more profoundly, comprehensibly and figuratively reveal the scientific concept of a museum exhibition.

Most often the personal documents are used in a museum space to create brighter and more multisided images of the important historical events, serving as control points of historical memory. As was truly noted by a researcher V. N. Badmayev, "historical memory especially peculiarly reacts to the tragic and dramatic historic events: wars, revolutions, repressions" (Badmayev, 2012). The $20^{\text {th }}$ century history is very rich for such events, among which the most significant and having the greatest impact on further development of the global history is the World War II. For the Russian Federation as the successor of the USSR, preservation of the historical memory about the Great Patriotic War is not only the constant of the invariance of the post-war world order, established by the Potsdam system, but also the key home-policy valueforming link of this succession. Celebrating the end of the Great Patriotic War on the $9^{\text {th }}$ of May, carrying out the "Immortal regiment", creating modern memorial compositions like a monument to the soldiers killed in the Rzhev battle - all this is "memorial places" for modern Russia. The exhibitions devoted to the Great Patriotic War have become an inseparable part of the museums reflecting the Russian history of the $20^{\text {th }}$ century. Besides, a large part of industrial or corporate museums, "museum rooms", "rooms of labor glory" necessarily contain exhibits or even full-fledged exhibitions devoted to this theme. The desire to immortalize the war years (the feat of labor, the contribution to Victory, the life of the whole generation) in the historical memory is another corroboration of the significance of this event for the national selfidentification of the Russian society.

\footnotetext{
${ }^{1}$ Informational maintenance of a museum exhibition can be implemented in various ways. The most traditional is labeling of the presented objects. Today, museums actively use "live" labels - reference material placed in sensor panels, tablets, screens, and museum kiosks. Another traditional way is to place additional information as texts, diagrams or charts on posters. A more modern variant is audio- or video support of a part of exhibition.
} 
The museum complexes of one of the Russian largest joint stock companies - the Russian Railroads - are no exception. The museum complex of Gorkiy railroad displays a lot of material exhibits of the Great Patriotic War epoch. These include objects of soldiers' everyday life, parts of uniform, awards, parts of weapons, etc. There are also tools used by railroad workers in the rear. The authentic objects are supplemented with models, paintings, and information blocks, presented in labels, showcases, sensor museum kiosks. The exhibition presents the tasks set by the government for railroads during the war years and characterizes the work of railroads in the rear and in the fronts.

Ego-documents - letters from the front and memoires of rear workers - are of special interest in the railroad museum exhibition. When researching them, we used the methods of phenomenological hermeneutics and anthropological, comparative and discourse analysis. The former includes analysis of the mechanisms of translating an individual subjective historical experience which served as the basis for forming the collective historical memory. Anthropological analysis helped to study the content of personal documents and reveal the impact of war events on the emotional state of people and their value attitudes. The comparative method allowed comprehensive analysis of the expression of subjective cultural practices in public sphere and comparison of the factual and emotional content of the narrative under study. The applied methods enabled to most comprehensively reconstruct the epoch - from the course of events to the inner psychological state of the front-line soldiers and their family members in the rear; they made it possible to trace and study the mechanisms of turning the subjective experience into the historical memory about war, to analyze the means of commemoration and the impact of modern museum technologies and new means of personal documents' representation on these processes. Also, the discourse analysis of the Russian and foreign historiography on the issues of correlation between the historical and collective memory, on the one hand, and the historical and public conscience, on the other, as well as their structure, forms of existence, interaction and interference, allowed tracing the genesis and transformations of these ideas in the modern practice of historical science.

\section{Results}

Museumification, or inclusion of a narration into a museum exhibition, is carried out with multimedia technologies (sensor screens, museum desks and kiosks, holographic panels and showcases), which allow translating the thoughts and emotional states of soldiers and their families without a guide's mediation. The multimedia content makes letters from the front accessible for a wide range of visitors (not only organized tourist groups but a lot of individual visitors who, as a rule, do not use a guide's services), "brings them to life", combining the opportunities for visual and audile perception. On the one hand, a digitalized document helps to preserve the paper carrier and graphic images (including ink and indelible pencil) from the action of the sun, artificial light, dust, moisture and other detrimental external factors. On the other hand, it provides their visualization, makes them available for detailed investigation, which is undoubtedly necessary for creating a full-fledged image and its commemoration. The appearance of letters, postcards, envelopes and official forms, demonstrated on the screens of sensor panels and museum kiosks, supplements the impression and enhances the perception of their content. The front triangle letters were covered with tiny handwriting on both sides, letter from home on one side, a soldier's response on the other. Under the deficit of paper, this way was often the only possible communication between the kin. Some letters were written on empty "killed in action" notices. The postcards illustrated with portraits of military leaders, pictures of Soviet soldiers and family life scenes or caricatures of the enemy - all were aimed at maintaining the high morale. They reflected the main line of the official ideology - "our cause is just", aimed at forming the inner motivation not to surrender but fight on. 
The additional opportunity of sound accompaniment of a letter or its part (professional reading, musical accompaniment) creates the effect of immersion into the reconstructed event. Besides, this option makes the document available for vision-impaired and blind people, thus broadening the audience.

The key feature of correspondence as a personal document is its individuality. A sheet of paper preserves not only a fact, an event, but also a person's perception of it (Makarova, 2016). Every line of a front triangle is passed through the personal, subjective, thus possessing the bright emotional character. The very first lines of a letter make its author not just a soldier but a person with their own individual life and fate. The impersonalized and to some extent abstract notion "a soldier of the Great Patriotic War" obtains the unique, unparalleled character. The image "comes to life". From a soldier's letter: "Good afternoon my highly respected Nyura Antonovna, highly respected mum. I am sending my warmest greetings to my dear son Vasiliy, also I am sending my warmest greetings to my dear son Lyonka" (MHGRD, MZHTL OF/436, sheet 1). It becomes apparent that before the war he had the life not connected with war in any way: a family, his mother, wife, beloved children, whom he does not cease thinking in a difficult situation. At the moment, the soldier worried more about the situation at home than his own fate: "We may come home from the front alive, we just should ask the God for mercy. All hope is on Him... I live well so far... I do not need money. I am fed and clothed. You take care of yourselves somehow. Your helpers are too small" (MHGRD, MZHTL OF/436, sheet 1). Tenderness to the kin fills the lines of letters: "In the first lines of my letter I give you a big kiss and thank you for not forgetting me so far. Then I am sending my greetings to the beloved and unforgettable, neither in the day nor at night, my son Evgeniy Sergeyevich and wishing him good health so that he grows big and waits for his dad home with victory" (MHGRD, MZHTL $\mathrm{OF} / 899$, sheet 2). In these simple and unsophisticated words, there is love to the kin which was a powerful motivation for struggle and invincible will for victory. A soldier is anxious not about his own life, but the lives of his kin: “... you wrote that people get sick with typhoid. But, dear Nadya, omehow save your and the children's health. Never drink raw water... as for the food, although everything is expensive, do not care about it, eat better... Sell my things, which are left, but, once again, eat better. If we are alive, we will get everything" (MHGRD, MZHTL $\mathrm{OF} / 899$, sheet 2). Several lines of the letter draw the way of life in the rear, spare diet, poor health, epidemics, high death rate. Taken as a whole, it creates the multidimensional perception of the war and war time.

The soldiers wrote briefly and sparingly about themselves: "So far I am alive, healthy, my health is good, we are fed well, all the more, we have lived till warm weather..." (MHGRD, MZHTL OF/899, sheet 2). That is all what the kin should know. The most frequent request to the family members is to write regularly: “...write letters more often, it will be merrier for me. Otherwise ... only one merriment: whistle of bullets and bursts of shells around" (MHGRD, MZHTL OF/638, sheet 1). Letters of the kin remain the only link to the past, pre-war life, to the habitual disposition.

The most dramatic component of the letters from the front is tidings about deaths. These are not the official "killed in action" notices but the letters of comrades-in-arms. Sometimes they do not dare to send this shattering news to the family of the killed, but inform their acquaintances or relatives: "You might have guessed that Sasha is not alive any more. He died a hero's death for the Motherland on the $29^{\text {th }}$ of June this year at Bobruisk town. I buried him not far from the village... and made a tomb inscription. He was twice an order-bearer, had a medal and a star, he was our best comrade... Tell about his death to family, his wife Shura..." (MHGRD, MZHTL OF/454, sheet 1).

Sometimes, there are lines characterizing the situation in the rear: "I am very glad that our secret services take profiteers by the throat. Otherwise, it's like some shed blood and others 
fill pockets" (MHGRD, MZHTL OF/459, sheet 2). These lines do not only establish a fact but give estimation, vividly supplementing the image and lifestyle of war workers.

No less interesting are the descriptions and characteristics of the military situation: "The battles are severe. We beat the German occupants to death, mercilessly, giving them no rest during days and nights. But, generally speaking, this is not a war, but a slaughter" (MHGRD, MZHTL OF/459, sheet 2). These lines show the personal attitude of the soldier to the enemy and the war. It is not one-sided but unambiguous. The war as the fact is apparently negatively estimated, as an unnatural and felonious action. On the other hand, liberating one's land from the enemy - "the occupant" - is the righteous deed, justifying death and cruelty of military operations.

While reading the soldiers' letters, we cease perceiving the war as a fact from a chronological row in a history textbook. It becomes a personal experience of everyone, despite being a past event (Rostovtsev and Sidorchuk, 2014). The relevant use of letters in a museum exhibition facilitates commemoration and allows forming the historical memory based on scientific data.

Narrative complexes help to not only reconstruct the military days, life and labor in the rear, but also to make these images closer and more accessible for perception. Based on the newspaper articles of the war period, which represented the official state ideological policy, and the memoires of railroad workers, representing the situation "from inside", one may restore the entire degree of responsibility, physical and emotional burden of labor in the railroads at that time. Often, women and teenagers did hard men's work. They did it as an everyday routine, implying nothing heroic in their labor. To truly comprehend the entire burden of their labor, one should fill the exhibition with their emotions and experiences. Such opportunity appeared due to the multimedia technologies, which made the reminiscences of those remote times "assume voice". From the memoires of E.A. Borodina (a movable crane operator): "Once we went to the depot with an engine driver Polyanskiy. ... I had to work both as a stocker and a driver assistant. It was hard, but I managed" (On locomotives..., n.d., pp. 92-93). An average locomotive tender of the pre-war period holds 18 tons of coal or firewood. That is about what a one-way trip takes. The fuel was loaded to a fire-box by hand, with a shovel, and on arrival at a station a locomotive brigade loaded the tender again. A break between the shifts (trips) was not longer than six hours. For technical failures - wrecks, derailments - people were punished severely.

Using memoires in the exhibition devoted to the rear enhances the figurative reconstruction of the days of labor and facilitates the reflection of historical memory. From the memoires of an engine driver Kozyrev: "At first, I thought that the girl would not cope with the work, would not manage. But I was mistaken... they firmly endured the whole burden... never complaining about tiredness. Although sometimes it was unbearable... they should have studied somewhere, go to a dancing ground, sleep in soft beds in the nights, but the war made them both in the nights and in any weather do the work beyond their strengths, the work not for girls" (On locomotives ..., n.d., pp. 28-29).

The memoires render not only the severity but also the dangers of working on the railroads during the war. Often the engine drivers of troop trains, evacuation and sanitary trains had to "play cat-and-mouse" with the German aviation, getting the train forwards and backwards: "I saw [the plane] coming towards us from the rear with an awful howl, I stopped the train and changed the movement direction. The fascist let out the bombs beside the target and with some desperate rage went for a new attempt, on the other side, and I changed the movement direction to the opposite side... If we did not struggle, did not put out the fascist's sight, he would definitely destroy us" (On locomotives ..., n.d., p. 79). In this case, the skillful 
work and coordinated actions of the locomotive brigade saved the lives of over 500 soldiers and officers, the train and equipment.

The reminiscences of railroad workers demonstrate their incredibly simple attitude to their labor in the war years. There are no regrets, nor pathetic elements or ideological load. Due to this, presentation of this narrative complex in a museum exhibition creates a deep and sincere image of everyday labor during the war time.

\section{Discussion}

The use of modern technologies in a museum space gives the opportunity to present the inner world of a person belonging to a definite historical epoch. Through museumification, nonmaterial culture forms as elements of traditional culture acquire value both for its carriers and in the conscience of the society in general (Bozhchenko, 2012, p. 113). Bringing the historical narrative to life in a museum space, making its content accessible for a wide range of visitors of various age and social groups, a museum enhances the attraction of written sources, which are usually hardly noticeable in exhibitions. However, these sources represent the historical-cultural image of the epoch, in this case the Great Patriotic War of 1941-1945. The wartime anthropology is manifested as a set of individual experiences and reminiscences, reflected in letters and memoires (Kuznetsov, 2016).

Estimating a museum's potential as the "memorial place", one cannot but mention recommemoration as a process of conscious oblivion of the past historical-psychological traumas. Recommemoration may be caused by the desire to overcome the common national guilt for a crime, the impossibility of the society's further development under the burden of the common national responsibility for the past. This, in particular, explains the specificity of denazification process in Germany or perception of collaborationism in France. The representatives of Frankfurt school T. Adorno (Adorno, 1963) and M. Horkheimer, applying a dialectic method in studying the influence of denazification on the formation of the post-war society in FRG, marked the effect of "weakened memory". The process of oblivion of historical facts, the use of "conjunctive mood" in interpretation of historical events leads mainly not to reconsideration of the past but becomes a means of manipulation in the modern political realities. We agree with the opinion by L.P. Repina, who rightfully marked that "the oblivion of the past can be the result of conscious manipulating of the public conscience" (Repina et al., 2019). Indeed, the conscious development and strengthening of the "weakened memory" or its elements in the socio-cultural content of the post-industrial informational society becomes an effective means of political struggle, used both by the official authorities and opposition.

The process of recommemoration is more complex in the modern Russian post-Soviet space. Sometimes, the "memorial place" includes both the embodiment of patriotic values and the manifestation of a "psychological trauma". The museum exhibitions devoted to the battle of Stalingrad may serve as an example: on the one hand, this battle is undoubtedly estimated as the main radical turn in the course of World War II; on the other hand, the name of I.V. Stalin is ambiguously perceived in connection with this event, including the desire of a certain part of the modern Russian society to return the previous name "Stalingrad" to today's Volgograd. In our opinion, one of the most disputable problems faced by a museum is the selectivity of historical memory. In this regard, the most important task of a museum as a memorial place is to maintain the scientific and objective character of the exhibition concept, relying on authentic sources, reconstructing a historical fact and, at the same time, reflecting and including it into the collective and historical memory of the nation (Mazur, 2019).

Historical reflection is inseparable from the general paradigm of humanitarian knowledge of the certain society. By a researcher O.G. Oexle, "of all national literatures of the 
$20^{\text {th }}$ century, the Russian one to the largest degree turns to "memory" (Oexle, 2008, p. 309). Indeed, the theme of the Great Patriotic War is the keynote of historical memory, permeating the art and literature of not only the Soviet epoch but also modern Russia. In our opinion, the temporality of the historical memory notion is not expressed in the narrowness of its limits or of historical knowledge as a whole, but is implemented in the interconnection of the collective and the individual in comprehending the historical cultural space.

As Maurice Halbwachs noted, "collective images are wrapped around individual memories" (Halbwachs, 2007). Letters from the front and memoires as expression of individual memory provide the opportunity for museum reflection to establish the functional interconnection with solving the modern problems of social self-identification. They not only preserve and translate the war-time facts, but enhance them with personal experiences. A soldier's letter, voiced and placed into the content of a museum kiosk, creates a unique audiovisual image of a person experiencing the horrors of war. The visual part makes it possible to descry in the minutest details a sheet of paper, the handwriting, or the lines of the front letter triangle. An off-screen voice recreates the emotions of the past, allowing the visitors to join them in the present. According to E.G. Trubina, memory serves as a link between the past and the present (Trubina, 2011, p. 38). The mechanism of "memorization", hence, is based on the living through the experience of the past generations as one's own personal experience; thus a strong interconnection between the past and the present is achieved, the succession of historical memory is implemented. In turn, the "personal" is better than the "abstract" assimilated by both the individual and the collective memory. The content of collective memory becomes the basis for forming the historical conscience.

The ideas of reflexive history, presented in the sociological and culturological researches of the $20^{\text {th }}$ century, highlight the correlation between the images of the past, "imagesreminiscences" and the principle of objectivity of historical knowledge. Often contrasting the notions of "historical memory" and "history of memory" (Repina, 2005), many researchers make a conclusion about the predominance of social communication during the process of the collective memory formation. In this regard, reflection, individual living through the images of the past comes to the foreground, to a large extent overshadowing not only the striving of the scientific cognition for maximal reconstruction, but also the problem of verification of the narratives and relics of the past. The modern museum space provides the opportunity to overcome this gnoseological contradiction. It is a museum that makes possible the convergence and joint use of the two conceptual methods of commemoration.

According to Yu.A. Levada, historical memory is based on both spontaneous and scientific means of reproducing its past by the society (Levada, 1969, p. 191). Modern museums can strengthen in the public conscience the interrelation between the scientific facts which are necessary for its self-identification and facilitate commemoration of the Great Patriotic War. That is how the fiber of historical conscience is woven, the objective facts are actualized, the historical memory of a particular event is maintained and passed down from one generation to another. The letters and memoires presented with the help of new technologies are a means to overcome the antagonism between the objectivity of historical knowledge and the local social groups' interpretation of history. This opportunity facilitates the museum reflection, provides commemoration, and forms the historical memory about the war.

\section{Conclusion}

Documents of personal origin, or ego-documents, combined with authentic objects, imagegraphical sources and additional informational accompaniment, constitute an accomplished complex of a museum exhibition, which is able to perform a broad functional, including historical memory actualization, thus implementing the mechanism of commemoration. 
Accessibility of both the visual and content parts of the letters from the front and memoires is an essential aspect of revealing the exhibition theme and forming the image of war time; it facilitates creating the appropriate mood in visitors, enhances the impact on historical memory, provides its socialization, and helps to demythologize the structure of the modern historical knowledge.

The utilitarian approach to interpreting the notion of "historical memory", contrasting the historical knowledge and the "collective memory", which has begun to show in the modern historiography, philosophy, and sociology, provides a lot of opportunities for creating various political myths. The political manipulation of historical knowledge builds the "demanded image" of historical memory, which may lead to a dramatically decreased influence of history on forming the national identity. Reconstructing the past solely through the prism of collective memory or through the demands of the social-political realities of the modern society would inevitably lead to degradation of humanitarian knowledge, to the increase of "natural oblivion" in the public conscience. The $20^{\text {th }}$ century history, aggravated by the negative consequences of the World War II, is perceived by the society predominantly through the more convenient and comfortable tools of "collective memory", with its basically corrected historical facts.

The narrative complex of a museum space is, in our opinion, one of the means which do not allow substituting historical knowledge for a mere "collective memory" about the past. On the contrary, it is museumification and representation of history through exhibition that make it possible to best combine the emotional-figurative and the scientific components, which most positively influences both the process of "memorizing" and the substantiation of the historical memory and, generally, historical culture of the society with scientific facts; this, in turn, bars manipulations with historical conscience by various political forces.

Thus, the use of a narrative complex in a museum space combined with the modern technological base provide an opportunity to visualize information, enhance its emotionalsensory perception, and create the effect of immersion into a historical epoch. This undoubtedly facilitates commemoration, formation of historical memory, bars the processes of "forgetting" and manipulations with historical facts.

\section{Sources and abbreviations}

1. MHGRD - Museum of the history of the Gorkiy railroad development. MZHTL OF/436 (Main fund). A.S. Polovnikov. A letter to wife Nyura of 09.06.1942.

2. MHGRD - Museum of the history of the Gorkiy railroad development. MZHTL OF/454 (Main fund). G. Bocharov. A letter from the front of 04.09.1944.

3. MHGRD - Museum of the history of the Gorkiy railroad development. MZHTL OF/459 (Main fund). T.S. Mishchikhin. A letter to wife Nadezhda Pavlovna of 30.09.1943.

4. MHGRD - Museum of the history of the Gorkiy railroad development. MZHTL OF/638 (Main fund). T.S. Mishchikhin. A letter to wife Nadezhda Pavlovna of 01.11.1943.

5. MHGRD - Museum of the history of the Gorkiy railroad development. MZHTL OF/899 (Main fund). T.S. Mishchikhin. A letter to wife Nadezhda Pavlovna of 16.04.1942.

6. MHGRD - Museum of the history of the Gorkiy railroad development. NN NV/F 470 (Scientific-auxiliary fund). On locomotives and locomotive workers. Memoires of the 
workers of the locomotive depot Gorkiy-Sortirovochniy, n.d., typewritten text, binding. Selfpublished.

\section{References}

Adorno, Th. W. (1963). Wasbedeutet: Aufarbeitungder Vergangenheit? Eingriffe. Neunkritische Modelle. Frankfurt am Main: Suhrkamp.

Badmaev, V. N. (2012). Mentality and historical memory. Vestnik Kalmytskogo universiteta, 1 (13), 78-84.

Bozhchenko, A. O. (2012). Historical memory as a form of museum reflection. Vestnik Sankt-Peterburgskkogo gosudarstvennogo universiteta kultury i iskusstv, 3 (12), 112-116.

Halbwachs, M. (2007). Social frameworks of memory. Transl. by S. N. Zenkin. Moscow: Novoye izdatelstvo. URL: https://www.academia.edu/29735881/M.KHalbvaks._Sotsialnye_ramki_pamyati (accessed 30.11.2020)

Kuznetsov, A. S. (2016). Letters from the front as a source for studying the anthropological content of the Great Patriotic War. Vestnik Kemerovskogo universiteta, 4, 63-68.

Leontyeva, O. B. (2015). "Memorial turn" in the modern Russian historical science. Dialog so vremenem. Almanakh intellektualnoy istorii, 50, 59-96.

Levada, Yu. A. (1969). Historical conscience and scientific method. Filosofskiye problemy istoricheskoy nauki. Moscow.

Mazur, L. N. (2019). Memorial museums of political figures in the space of historical memory of modern Russia. Dialog so vremenem. Almanakh intellektualnoy istorii, 66, 100-119.

Makarova, N. N. (2016). “As long as i am alive - i will write...”. Noveyshaya istoriya Rossii, 3, 159-174.

Navarro, O. (2010). History and memory in a modern museum: several comments from the viewpoint of critical museology. Voprosy muzeologii, 2, 7-8.

Nora, P. (1999). Issues of memorial places. France-memory: collection of scientific works. Saint Petersburg: Saint Petersburg University Publishers.

Oexle, O. G. (2008). History of memory - the new paradigm of historical science. In: L. P. Repina (ed.) Theories and methods of historical science: a step to the $21^{\text {st }}$ century. Works of International scientific conference. Moscow: Institut vseobshchey istorii RAN.

Ovchinnikova, Z. A. (2017). Museum in the context of social-cultural transformations of an informational society. Vestnik kultury i iskusstv, 3 (51), 43-48.

Repina, L. P. (2005). Concepts of social and cultural memory in the modern historiography. In: Phenomenon of the past. Collection of articles. Moscow.

Repina, L. P. (2010). Representations of the past and connections of epochs in the historical conscience. Images of epochs and historical representations: Russia East - West. Moscow: Krug.

Repina, L. P., Zvereva, V. V. \& Paramonova, M. Yu. (2019). History of historical knowledge. Moscow: Yurayt. URL: http://disus.ru/knigi/422711-1-repina-lorinapetrovna-zvereva-vera-vladimirovna-paramonova-marina-yurevna-istoriyaistoricheskogo-znaniya-udk.php (accessed 30.11.2020) 
Rostovtsev, E. A. \& Sidorchuk, I. V. (2014). Museum and historical memory in modern Russia. Voprosy muzeologoii, 2 (10), 16-21.

Smirnov, A. V. (2016). Modern museum: communication or commemoration. Muzey: pamyat i proektsii budushchego, 3(24), 17-24.

Trubina, E. G. (2011). Learning to recall: vectors of memory research. In: V. N. Yarskaya, E. R. Yarskaya-Smirnova (eds.) Power of time: social boundaries of memory. Collection of works. Moscow: Variant. 